\title{
Article \\ Effect of Catalyst Crystallinity on V-Based Selective Catalytic Reduction with Ammonia
}

\author{
Min Seong Lee ${ }^{1,2,+}$, Sun-I Kim ${ }^{1,+}$, Myeung-jin Lee ${ }^{1}$, Bora Ye ${ }^{1}$, Taehyo Kim ${ }^{1}$, Hong-Dae Kim ${ }^{1} \mathbb{1}$, \\ Jung Woo Lee ${ }^{2, *}$ (i) and Duck Hyun Lee ${ }^{1, *(1)}$
}

1 Green Materials and Processes R\&D Group, Korea Institute of Industrial Technology, Ulsan 44413, Korea; qneh5@kitech.re.kr (M.S.L.); sunikim@kitech.re.kr (S.-I.K.); leemj@kitech.re.kr (M.-j.L.); yebora@kitech.re.kr (B.Y.); thkim0215@kitech.re.kr (T.K.); hdkim@kitech.re.kr (H.-D.K.)

2 Department of Materials Science \& Engineering, Pusan National University, Busan 46241, Korea

* Correspondence: jungwoolee@pusan.ac.kr (J.W.L.); dulee@kitech.re.kr (D.H.L.); Tel.: +82-51-510-2898 (J.W.L.); +82-52-980-6709 (D.H.L.); Fax: +82-52-980-6669 (D.H.L.)

+ These authors contributed equally to this study and should be considered as co-first authors.

check for updates

Citation: Lee, M.S.; Kim, S.-I; Lee, M.-j.; Ye, B.; Kim, T.; Kim, H.-D.; Lee, J.W.; Lee, D.H. Effect of Catalyst Crystallinity on V-Based Selective Catalytic Reduction with Ammonia. Nanomaterials 2021, 11, 1452. https:// doi.org/10.3390/nano11061452

Academic Editor: Maria Filipa Ribeiro

Received: 4 May 2021

Accepted: 24 May 2021

Published: 30 May 2021

Publisher's Note: MDPI stays neutral with regard to jurisdictional claims in published maps and institutional affiliations.

Copyright: (c) 2021 by the authors. Licensee MDPI, Basel, Switzerland. This article is an open access article distributed under the terms and conditions of the Creative Commons Attribution (CC BY) license (https:// creativecommons.org/licenses/by/ $4.0 /)$.

\begin{abstract}
In this study, we synthesized $\mathrm{V}_{2} \mathrm{O}_{5}-\mathrm{WO}_{3} / \mathrm{TiO}_{2}$ catalysts with different crystallinities via one-sided and isotropic heating methods. We then investigated the effects of the catalysts' crystallinity on their acidity, surface species, and catalytic performance through various analysis techniques and a fixed-bed reactor experiment. The isotropic heating method produced crystalline $\mathrm{V}_{2} \mathrm{O}_{5}$ and $\mathrm{WO}_{3}$, increasing the availability of both Brønsted and Lewis acid sites, while the one-sided method produced amorphous $\mathrm{V}_{2} \mathrm{O}_{5}$ and $\mathrm{WO}_{3}$. The crystalline structure of the two species significantly enhanced $\mathrm{NO}_{2}$ formation, causing more rapid selective catalytic reduction (SCR) reactions and greater catalyst reducibility for $\mathrm{NO}_{X}$ decomposition. This improved $\mathrm{NO}_{X}$ removal efficiency and $\mathrm{N}_{2}$ selectivity for a wider temperature range of $200{ }^{\circ} \mathrm{C}-450{ }^{\circ} \mathrm{C}$. Additionally, the synthesized, crystalline catalysts exhibited good resistance to $\mathrm{SO}_{2}$, which is common in industrial flue gases. Through the results reported herein, this study may contribute to future studies on SCR catalysts and other catalyst systems.
\end{abstract}

Keywords: selective catalytic reduction; V-based catalyst; $\mathrm{NO}_{\mathrm{X}}$ removal efficiency; crystallinity; isotropic heating

\section{Introduction}

Air pollution has recently become a critical, global issue [1]. In response, environmental regulations have been tightened to reduce the emissions of chemical impurities (such as $\mathrm{NO}_{X}, \mathrm{SO}_{x}, \mathrm{CO}$, volatile organic compounds (VOCs), and particulate matter (PM)) from power plants, boilers, and mobile sources [2,3]. Among the numerous air pollutants, nitrogen oxides $\left(\mathrm{NO}_{\mathbf{X}}\right.$ : $\mathrm{NO}, \mathrm{NO}_{2}$, and $\left.\mathrm{N}_{2} \mathrm{O}\right)$ are extremely dangerous as they can easily disperse over long distances and form secondary $\mathrm{PM}_{2.5}$ by reacting with water vapor, which causes acid rain and smog, contributes to global warming [4,5], and can deeply penetrate human lungs, causing adverse health effects such as increased cardiovascular and respiratory morbidity [6].

Owing to the harmful effects of NOx, several technologies, such as selective catalytic reduction (SCR), selective noncatalytic reduction (SNCR), and non-selective catalytic reduction (NSCR), have been used to reduce NOx emissions. SCR with ammonia, which converts $\mathrm{NO}_{X}$ in fuel gas into $\mathrm{N}_{2}$ and $\mathrm{H}_{2} \mathrm{O}$, is the most efficient $\mathrm{NO}_{X}$ removal technology, as the process emits no secondary pollutants and can reduce NOx emissions by $80-100 \%$ at a relatively low temperature (approximately $350^{\circ} \mathrm{C}$ ) $[7,8]$.

Commercially, $\mathrm{V}_{2} \mathrm{O}_{5}-\mathrm{WO}_{3} / \mathrm{TiO}_{2}$ has been used as an SCR catalyst due to the strong catalytic activity of $\mathrm{V}_{2} \mathrm{O}_{5}$, and lower oxidation activity for the conversion of $\mathrm{SO}_{2}$ to $\mathrm{SO}_{3}$ in fuel gas. However, it has a narrow, high activation temperature range $\left(300-400{ }^{\circ} \mathrm{C}\right)$, and its 
performance is reduced at low temperatures (below $300{ }^{\circ} \mathrm{C}$ ), which induce the oxidation of $\mathrm{SO}_{2}$ to $\mathrm{SO}_{3}[9,10]$. The flue gas temperature of industrial processes is typically as low as $300{ }^{\circ} \mathrm{C}$, and the temperature of diesel engines has a wide range $\left(100-400{ }^{\circ} \mathrm{C}\right)[5,11]$. Therefore, the use of $\mathrm{V}_{2} \mathrm{O}_{5}-\mathrm{WO}_{3} / \mathrm{TiO}_{2}$ is restricted and requires adjustment, such as in the form of upstream installation and desulfurization.

Extensive studies have been conducted to develop new catalysts that can be effective under a low and wide temperature range of $200-450{ }^{\circ} \mathrm{C}$. For example, Liu et al. designed a W-promoted $\mathrm{MnO}_{x}$ catalyst $\left(\mathrm{MnWO}_{x}\right)$ composed of a unique core-shell structure with $\mathrm{Mn}_{3} \mathrm{O}_{4}$ surrounded by $\mathrm{Mn}_{5} \mathrm{O}_{8}$, and achieved a high $\mathrm{NOx}$ reduction efficiency from $60{ }^{\circ} \mathrm{C}$ to $250{ }^{\circ} \mathrm{C}$ [12]. Huang et al. fabricated multi-walled carbon nanotube (CNT)-supported vanadium catalysts, in which vanadium particles were highly dispersed on the walls of the carbon nanotubes, which exhibited excellent activity in the SCR of NO at $100-250{ }^{\circ} \mathrm{C}$ [13]. However, the utilization of these catalysts in industrial fields is limited, as the catalysts are only activated at low temperatures, and they are deactivated when they come in to contact with the sulfur and water in exhaust gas at low temperatures below $300{ }^{\circ} \mathrm{C}$ [14,15].

The activity of catalytic materials is closely related to their crystalline structure $[16,17]$. Wang et al. reported that the formation of crystalline tungsten oxide on the surface of titania results in higher water resistance and $\mathrm{NO}_{X}$ removal efficiency at temperatures below $250{ }^{\circ} \mathrm{C}$ than those achieved by amorphous tungsten oxide [18]. Inomata et al. reported that $\mathrm{V}_{2} \mathrm{O}_{5} \mathrm{SCR}$ catalysts with low crystallinity achieved better catalytic performance than that of $\mathrm{V}_{2} \mathrm{O}_{5}$ with high crystallinity [19]. They also reported that the crystalline $\mathrm{V}_{2} \mathrm{O}_{5}$ has a higher catalytic performance than amorphous $\mathrm{V}_{2} \mathrm{O}_{5}$ under the same sintering conditions [20]. Recently, many studies have been conducted on V-base SCR catalysts to enhance catalytic activity under low temperature $[21,22]$. However, the effect of catalyst crystallinity on the performance of V-based SCR catalysts remains unknown.

In this study, we explored the effect of crystallinity of $\mathrm{V}_{2} \mathrm{O}_{5}-\mathrm{WO}_{3} / \mathrm{TiO}_{2}$ on the $\mathrm{NO}_{\mathrm{X}}$ removal efficiency and improved the catalytic performance under temperatures ranging from $200{ }^{\circ} \mathrm{C}$ to $450{ }^{\circ} \mathrm{C}$ by controlling the crystallinity, with excellent thermal stability. The crystallinity of the $\mathrm{V}_{2} \mathrm{O}_{5}$ and $\mathrm{WO}_{3}$ catalysts was adjusted by altering the heating methods, and this was evaluated via transmission electron microscopy (TEM), X-ray diffraction (XRD), Raman, and selected area electron diffraction (SAED) analyses.

\section{Materials and Methods}

\subsection{Synthesis of $\mathrm{V}_{2} \mathrm{O}_{5}-\mathrm{WO}_{3} / \mathrm{TiO}_{2}$ Catalysts}

Catalysts containing 2 wt.\% and 10 wt.\% of $\mathrm{V}_{2} \mathrm{O}_{5}$ and $\mathrm{WO}_{3} / \mathrm{TiO}_{2}$ were prepared following the impregnation method, respectively. $\mathrm{NH}_{4} \mathrm{VO}_{3}(0.256 \mathrm{~g}, 99.99 \%$, Sigma-Aldrich Inc., St. Louis, MO, USA) and $\left(\mathrm{NH}_{4}\right)_{6} \mathrm{H}_{2} \mathrm{~W}_{12} \mathrm{O}_{40} \times \mathrm{H}_{2} \mathrm{O}(1.062$ g, 99.99\%, Sigma-Aldrich Inc., St. Louis, MO, USA) were dissolved in $100 \mathrm{~mL}$ of deionized water with oxalic acid (0.386 g, 99.999\%, Sigma-Aldrich Inc., St. Louis, MO, USA), which acted as a solubility agent. $\mathrm{TiO}_{2}$ powder (8.800 g, NT-01, NANO Co., Ltd., Sang-ju, Republic of Korea) was mixed with the prepared solution, and the mixture was stirred for $2 \mathrm{~h}$. The amorphous $\mathrm{V}_{2} \mathrm{O}_{5}-\mathrm{WO}_{3} / \mathrm{TiO}_{2}$ catalyst was prepared by drying the mixture on one side by heating the bottom of the beaker with a hot plate, while the crystalline $\mathrm{V}_{2} \mathrm{O}_{5}-\mathrm{WO}_{3} / \mathrm{TiO}_{2}$ catalyst was prepared following the isotropic heating method, in which the beaker was submerged in an oil bath. The prepared samples were dried at $110^{\circ} \mathrm{C}$ for $12 \mathrm{~h}$, and the obtained powders were then calcined at $500{ }^{\circ} \mathrm{C}$ in a furnace for $5 \mathrm{~h}$ under atmospheric pressure.

\subsection{Catalyst Characterization}

The surface morphology and elemental composition of the samples were investigated by field emission scanning electron microscopy (FE-SEM, model: SU8020/Hitachi, Tokyo, Japan), transmission electron microscope (TEM, model: JEM-2100F/JEOL Ltd., Tokyo, Japan), and electron energy loss spectroscopy (EELS) at an accelerating voltage of $10.0 \mathrm{kV}$. Additionally, we analyzed the extent of crystallinity using X-Ray Diffraction (XRD, model: Ultima IV / Rigaku, Tokyo, Japan) with $\mathrm{Cu} K \alpha(\lambda=0.15406 \mathrm{~nm})$ radiation 
in the $2 \theta$ range from $20^{\circ}$ to $80^{\circ}$ at a scan rate of $1^{\circ} / \mathrm{min}$. The Raman spectra (Raman, model: alpha300s/WITec, Ulm, Germany) were measured using a $532 \mathrm{~nm}$ laser to generate an excited state to observe the structure of the catalysts. The textural properties were analyzed following the Brunauer-Emmett-Teller (BET, model: ASAP2020/Micromeritics Instrument Corp., Norcross, USA) method. X-ray photoelectron spectroscopy (XPS, model: $\mathrm{K}$ Alpha+/Thermo Scientific, Waltham, USA) was conducted with Al K $\alpha$ radiation to confirm the oxidation states of the samples, and the binding energy of C1s was normalized as $284.8 \mathrm{eV}$. The reduction properties of the catalyst materials were measured by $\mathrm{NH}_{3}$-temperature-programmed desorption $\left(\mathrm{NH}_{3}\right.$-TPD, model: AutoChem II 2920/Micromeritics Instrument Corp, Norcross, USA). The samples were pretreated at $150{ }^{\circ} \mathrm{C}$ in a current of $\mathrm{N}_{2}$ for $4 \mathrm{~h}$ to remove physiosorbed $\mathrm{NH} 3$ species and organic matters, and $\mathrm{NH}_{3}$ was then adsorbed with $10 \% \mathrm{NH}_{3} / \mathrm{He}$ gas at $150{ }^{\circ} \mathrm{C}$ for $1 \mathrm{~h}$. The TPD experiment was conducted under a temperature range of $100-900{ }^{\circ} \mathrm{C}$. A $\mathrm{H}_{2}$-temperature-programmed reduction $\left(\mathrm{H}_{2}\right.$-TPR, model: AutoChem II 2920/Micromeritics Instrument Corp, Norcross, USA) experiment was conducted, during which the samples were immersed in a current of $10 \% \mathrm{H}_{2} / \mathrm{Ar}$ in the $150-900{ }^{\circ} \mathrm{C}$ temperature range.

\subsection{Catalytic Measurement}

The $\mathrm{NH}_{3}$-SCR activities were evaluated in a fixed-bed reactor under high atmospheric pressure. The operating temperature was varied from $200{ }^{\circ} \mathrm{C}$ to $500{ }^{\circ} \mathrm{C}$, and the reactive gas was composed of $300 \mathrm{ppm}$ each of $\mathrm{NO}, \mathrm{NH}_{3}\left(\mathrm{NH}_{3} / \mathrm{NO}_{\mathrm{X}}=1.0\right), \mathrm{SO}_{2}$, and $5 \mathrm{vol} \%$ of $\mathrm{O}_{2}$ with a balance of $\mathrm{N}_{2}$ at a total flow rate of $500 \mathrm{sccm}$. During evaluation, $0.35 \mathrm{mg}$ of the powder catalyst (sieved to 40-60 mesh) was tested, which yielded a gas hourly space velocity (GHSV) of $60,000 \mathrm{~h}^{-1}$. The reactive gas concentration was continuously monitored via Fourier transform-infrared spectroscopy (model: CX-4000/Gasmet, Vantaa, Finland) and $\mathrm{O}_{2}$ analyzer (Oxitec 5000, Marienheide, Germany). The $\mathrm{NO}_{X}$ removal efficiency and $\mathrm{N}_{2}$ selectivity were calculated according to Equations (1) and (2), respectively.

$$
\begin{gathered}
\mathrm{NO} \text { removal efficiency }(\%)=\frac{\mathrm{NO}_{\mathrm{X} \text { inlet }}-\mathrm{NO}_{\mathrm{X} \text { outlet }}}{\mathrm{NO}_{\mathrm{X} \text { inlet }}} \times 100, \\
\mathrm{~N}_{2} \text { selectivity }(\%)=1-\frac{2 \mathrm{~N}_{2} \mathrm{O}_{\text {outlet }}}{\mathrm{NO}_{\mathrm{X} \text { inlet }}+\mathrm{NH}_{3} \text { inlet }-\mathrm{NO}_{\mathrm{X} \text { outlet }}-\mathrm{NH}_{3 \text { outlet }}} \times 100,
\end{gathered}
$$

\section{Results and Discussion}

Figure 1 shows the SEM $(a, b)$ and TEM $(c, d)$ images of the $\mathrm{V}_{2} \mathrm{O}_{5}-\mathrm{WO}_{3} / \mathrm{TiO}_{2}$ catalysts prepared following the one-sided heating $(\mathrm{a}-\mathrm{c})$ and isotropic heating $(\mathrm{b}-\mathrm{d})$ methods. Both prepared $\mathrm{V}_{2} \mathrm{O}_{5}-\mathrm{WO}_{3} / \mathrm{TiO}_{2}$ catalysts exhibited similar particle sizes, shapes with diameters ranging from $15 \mathrm{~nm}$ to $50 \mathrm{~nm}$, specific surface areas, pore volumes, and pore sizes (Table 1). The catalyst particles were composed of $\mathrm{V}_{2} \mathrm{O}_{5}$ and $\mathrm{WO}_{3}$ nanoparticles on $\mathrm{TiO}_{2}$ supports. It should be noted that the prepared nanoparticles were similar in size to the $\mathrm{TiO}_{2}$ powders [23]. The insets of Figure 1c,d show the EELS elemental mapping of the prepared catalysts, in which the red, blue, and green areas indicate $\mathrm{V}, \mathrm{W}$, and Ti, respectively. The $\mathrm{V}_{2} \mathrm{O}_{5}$ and $\mathrm{WO}_{3}$ were uniformly distributed on the $\mathrm{TiO}_{2}$ supports with no agglomeration, confirming that the drying process did not affect the morphology of the prepared catalysts. Table 2 shows the $\mathrm{V}_{2} \mathrm{O}_{5}, \mathrm{WO}_{3}$, and $\mathrm{TiO}_{2}$ weight fractions of the catalysts, respectively.

Table 1. Brunauer-Emmet-Teller (BET) results of the $\mathrm{V}_{2} \mathrm{O}_{5}-\mathrm{WO}_{3} / \mathrm{TiO}_{2}$ prepared by the one-sided heating and isotropic heating methods.

\begin{tabular}{cccc}
\hline Sample & BET Surface Area; $\mathbf{S}_{\text {BET }}\left(\mathbf{m}^{2} / \mathbf{g}\right)$ & Pore Volume $\left(\mathbf{c m}^{\mathbf{3}} / \mathbf{g}\right)$ & Pore Size $(\mathbf{n m})$ \\
\hline One-sided & 69.6 & 0.252 & 14.48 \\
Isotropic & 70.2 & 0.257 & 14.67 \\
\hline
\end{tabular}


(a)

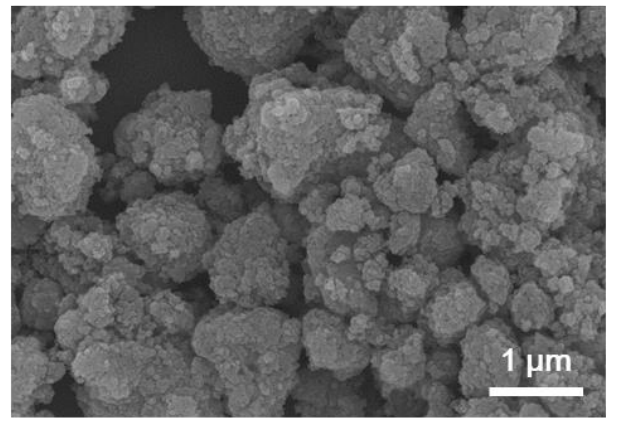

(c)

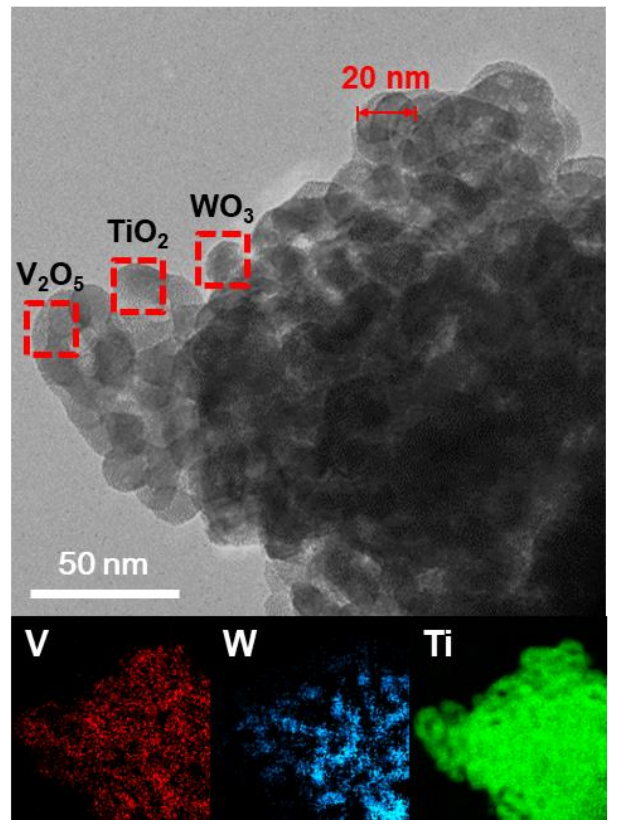

(b)

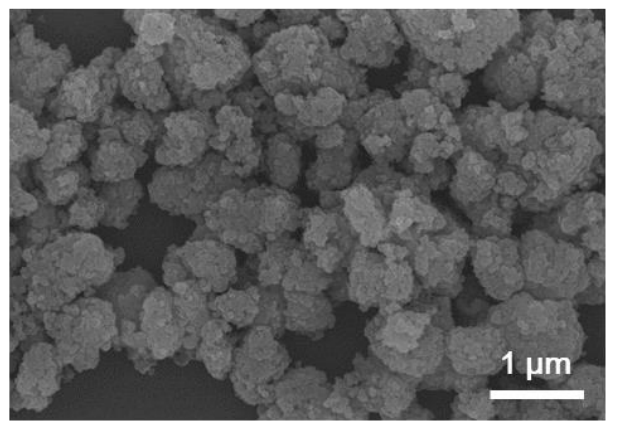

(d)

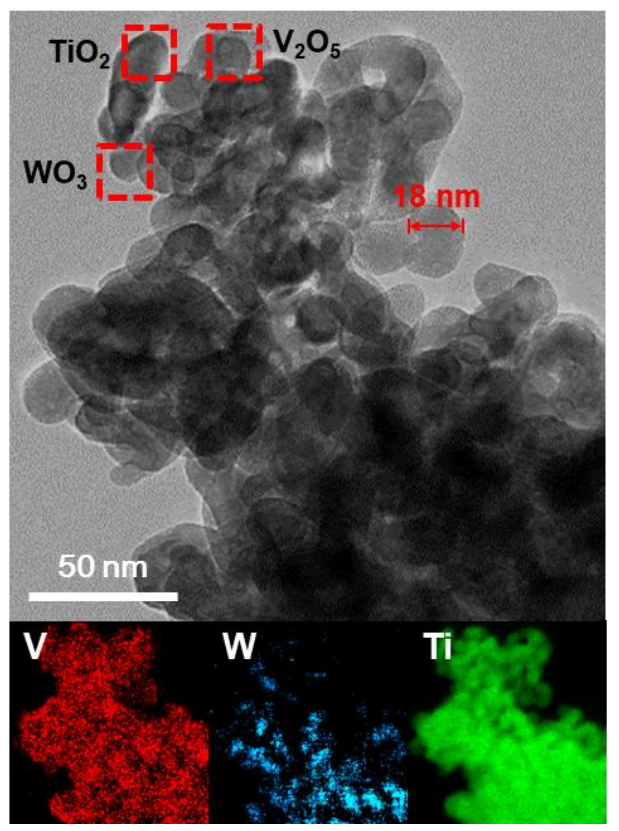

Figure 1. SEM images of the $\mathrm{V}_{2} \mathrm{O}_{5}-\mathrm{WO}_{3} / \mathrm{TiO}_{2}$ prepared by the (a) one-sided heating and (b) isotropic heating methods. TEM images of the $\mathrm{V}_{2} \mathrm{O}_{5}-\mathrm{WO}_{3} / \mathrm{TiO}_{2}$ prepared by the (c) one-sided heating and (d) isotropic heating methods (insets show the EELS elemental mapping of $\mathrm{V}, \mathrm{W}$, and Ti).

Table 2. X-ray fluorescence analysis of the $\mathrm{V}_{2} \mathrm{O}_{5}-\mathrm{WO}_{3} / \mathrm{TiO}_{2}$ prepared by the one-sided heating and isotropic heating methods.

\begin{tabular}{cccccc}
\hline Sample & $\mathrm{TiO}_{\mathbf{2}}$ & $\mathrm{WO}_{\mathbf{3}}$ & $\mathbf{V}_{\mathbf{2}} \mathbf{O}_{\mathbf{5}}$ & $\mathbf{S O}_{\mathbf{3}}$ & $\mathbf{S i O}_{\mathbf{2}}$ \\
\hline One-sided & 86.92 & 10.19 & 2.02 & 0.70 & 0.17 \\
Isotropic & 87.05 & 10.04 & 2.03 & 0.66 & 0.22 \\
\hline
\end{tabular}

XRD measurements were taken to analyze the impact of the heating method on the crystalline structures of the prepared catalysts (Figure 2a). The prepared samples exhibit clear anatase $\mathrm{TiO}_{2}$ signals, $\mathrm{V}_{2} \mathrm{O}_{5}$ and $\mathrm{WO}_{3}$ signals were not observed because they are spread uniformly with low concentration [24]. Raman analysis was also conducted to determine how the heating conditions affected the structure of the $\mathrm{V}_{2} \mathrm{O}_{5}-\mathrm{WO}_{3} / \mathrm{TiO}_{2}$, as shown in Figure $2 \mathrm{~b}$,c. The spectra of the $\mathrm{V}_{2} \mathrm{O}_{5}-\mathrm{WO}_{3} / \mathrm{TiO}_{2}$ catalysts contained peaks at $144.7,197.3,401.5,518.5$, and $639.1 \mathrm{~cm}^{-1}$, in the spectra, which are typical of anatase $\mathrm{TiO}_{2}$ (Figure 2b) [25]. Figure 2c shows the structure of the vanadium and tungsten oxides in the $700-1100 \mathrm{~cm}^{-1}$ range. As active sites of $\mathrm{V}_{2} \mathrm{O}_{5}-\mathrm{WO}_{3} / \mathrm{TiO}_{2}$ catalysts in SCR reactions, the state of the vanadium oxide species on the surface of the $\mathrm{V}_{2} \mathrm{O}_{5}-\mathrm{WO}_{3} / \mathrm{TiO}_{2}$ plays a key role in its catalytic behavior [26]. The band at $988.7 \mathrm{~cm}^{-1}$ could be attributed to the $\mathrm{V}-\mathrm{O}$ vibration of crystalline $\mathrm{V}_{2} \mathrm{O}_{5}$, and the bands at $800.5 \mathrm{~cm}^{-1}$ were associated with the $\mathrm{W}-\mathrm{O}-$ $\mathrm{W}$ stretching of octahedrally coordinated W units [27-29]. The Raman spectra showed that 
the $\mathrm{V}_{2} \mathrm{O}_{5}-\mathrm{WO}_{3} / \mathrm{TiO}_{2}$ catalyst prepared by isotropic heating had high crystallinity, while that prepared by one-sided heating was mostly amorphous.

(a)

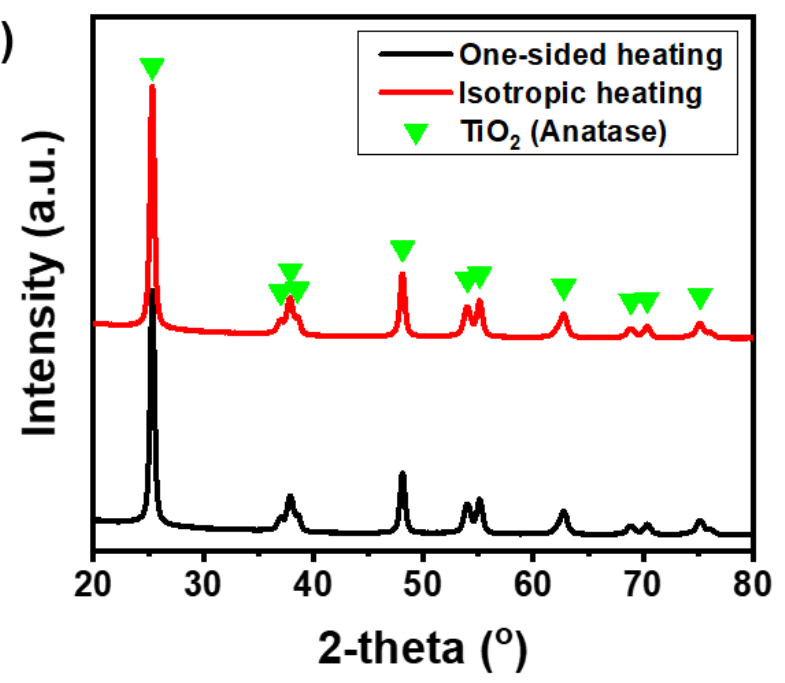

(b)

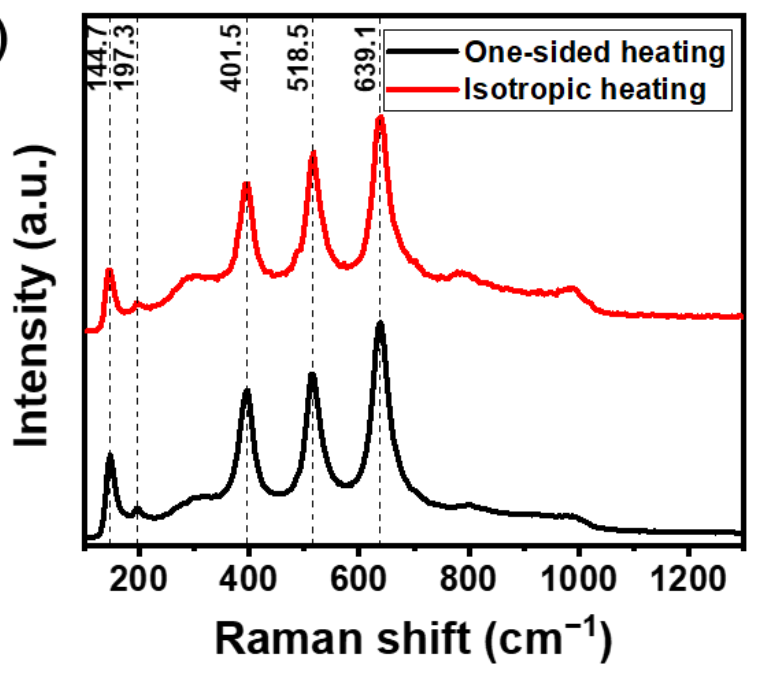

(c)

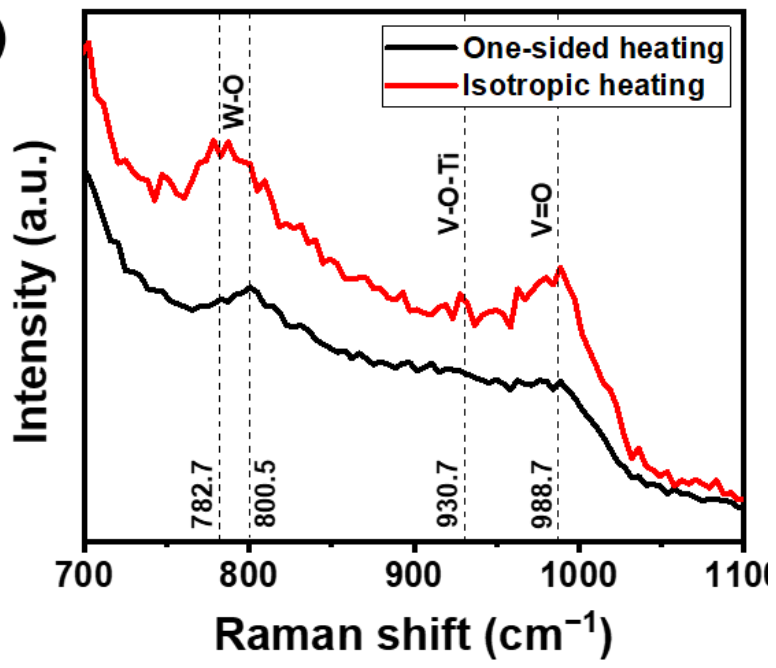

Figure 2. (a) XRD patterns and (b,c) Raman spectra of $\mathrm{V}_{2} \mathrm{O}_{5}-\mathrm{WO}_{3} / \mathrm{TiO}_{2}$ with different structures (black and red lines represent the $\mathrm{V}_{2} \mathrm{O}_{5}-\mathrm{WO}_{3} / \mathrm{TiO}_{2}$ prepared by the one-sided heating and isotropic heating methods, respectively). 
To further investigate the crystallinity of the prepared catalysts, we also compared the SAED patterns of the catalysts prepared using the one-sided heating (Figure $3 \mathrm{a}-\mathrm{c}$ ) and isotropic (Figure $3 \mathrm{~d}-\mathrm{f}$ ) heating methods. In the SAED patterns, single spots only become visible when the beam is diffracted by a single crystal; however, amorphous materials yield ring patterns [30,31]. The diffraction patterns of $\mathrm{V}_{2} \mathrm{O}_{5}$ and $\mathrm{WO}_{3}$ prepared by the one-sided heating method were ring-shaped (Figure 3a-b), indicating amorphous structures [32]. However, those prepared following the isotropic heating method exhibited clear crystalline diffraction (Figure 3d,e). The $\mathrm{TiO}_{2}$ nanoparticles maintained their anatase structure, even after the application of heat treatment (Figure 3c,f). This indicates that the crystallinity of the catalyst was greatly affected by the heating conditions. That is, one-sided heating produced an amorphous $\mathrm{V}_{2} \mathrm{O}_{5}-\mathrm{WO}_{3} / \mathrm{TiO}_{2}$ catalyst, while isotropic heating produced a crystalline $\mathrm{V}_{2} \mathrm{O}_{5}-\mathrm{WO}_{3} / \mathrm{TiO}_{2}$ catalyst.

(a)

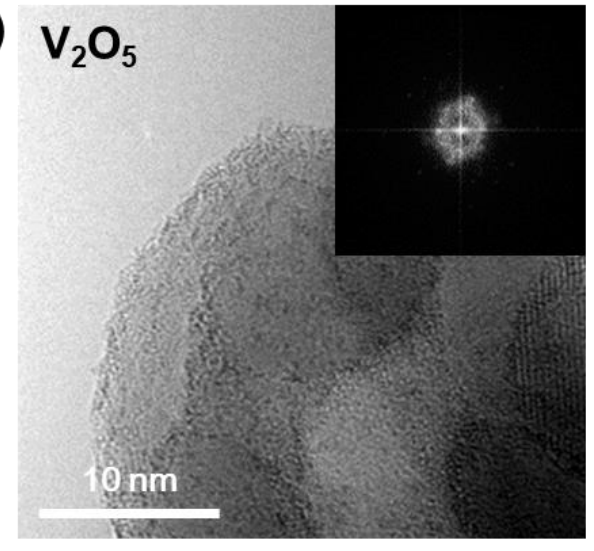

(b)

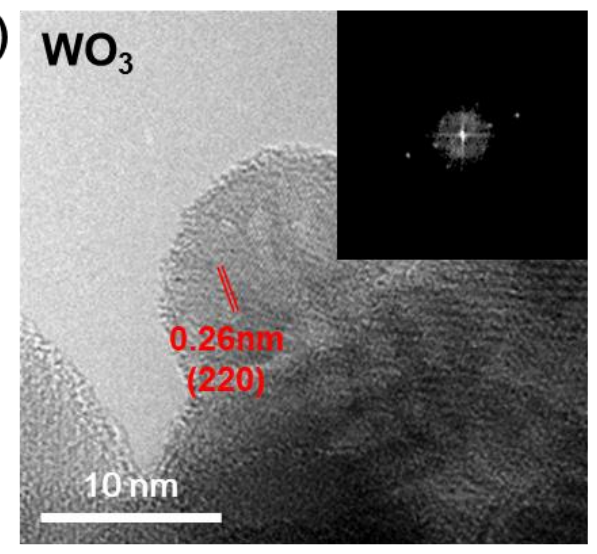

(c)

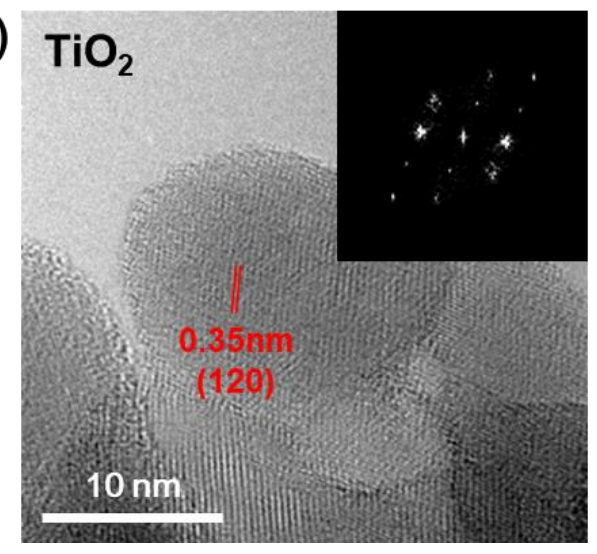

(d)

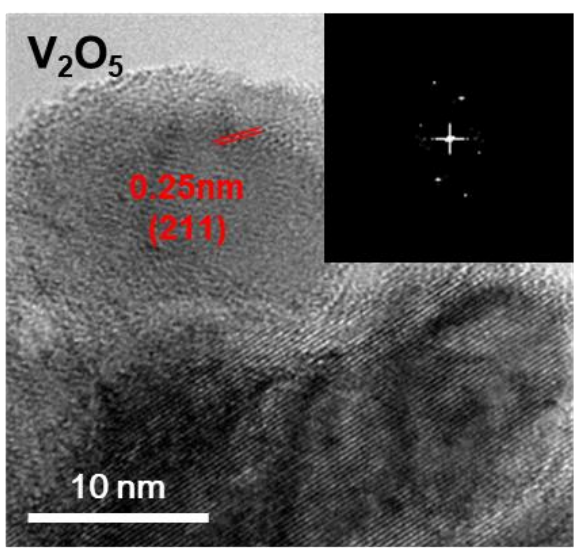

(e)

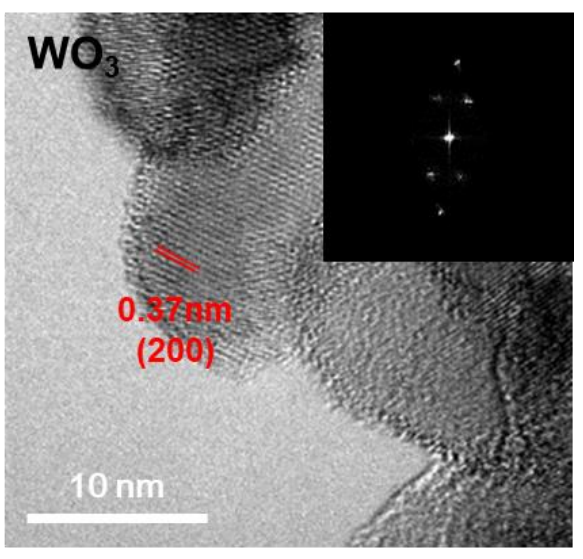

(f)

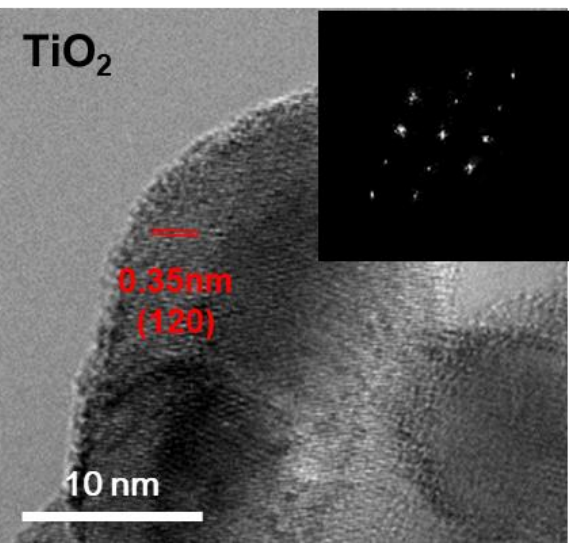

Figure 3. TEM images and SAED patterns (inset) of the $\mathrm{V}_{2} \mathrm{O}_{5}-\mathrm{WO}_{3} / \mathrm{TiO}_{2}$ prepared by (a-c) one-sided heating and $(\mathbf{d}-\mathbf{f})$ isotropic heating methods. 
To identify the effect of the crystallinity of $\mathrm{V}_{2} \mathrm{O}_{5}-\mathrm{WO}_{3} / \mathrm{TiO}_{2}$ on its SCR performance, its $\mathrm{NO}_{X}$ removal efficiencies were measured in a fixed bed (Figure $4 \mathrm{a}-\mathrm{c}$ ). We found that the $\mathrm{NO}_{\mathrm{X}}$ removal efficiency of the amorphous $\mathrm{V}_{2} \mathrm{O}_{5}-\mathrm{WO}_{3} / \mathrm{TiO}_{2}$ catalyst was negatively impacted at temperatures below $300{ }^{\circ} \mathrm{C}$; however, it exceeded $94 \%$ at $300-400{ }^{\circ} \mathrm{C}$. The crystalline $\mathrm{V}_{2} \mathrm{O}_{5}-\mathrm{WO}_{3} / \mathrm{TiO}_{2}$ catalyst achieved a $\mathrm{NO}$ removal efficiency of $82 \%$ at $200{ }^{\circ} \mathrm{C}$; thus, it was $27 \%$ more efficient than the amorphous $\mathrm{V}_{2} \mathrm{O}_{5}-\mathrm{WO}_{3} / \mathrm{TiO}_{2}$ catalyst. Moreover, the efficiency increased to $100 \%$ in the temperature range of $240-400{ }^{\circ} \mathrm{C}$ (Figure $4 \mathrm{a}$ ). $\mathrm{NH}_{3}$ conversion of amorphous and crystalline $\mathrm{V}_{2} \mathrm{O}_{5}-\mathrm{WO}_{3} / \mathrm{TiO}_{2}$ also showed a similar to the $\mathrm{NO}_{\mathrm{X}}$ conversion value (Figure S1). Figure $4 b$ shows the $\mathrm{N}_{2}$ selectivity of the $\mathrm{V}_{2} \mathrm{O}_{5}-\mathrm{WO}_{3} / \mathrm{TiO}_{2}$ catalysts at different temperatures. A trace amount of $\mathrm{N}_{2} \mathrm{O}$ in the amorphous and crystalline $\mathrm{V}_{2} \mathrm{O}_{5}-\mathrm{WO}_{3} / \mathrm{TiO}_{2}$ was generated at $350{ }^{\circ} \mathrm{C}$, and the $\mathrm{N}_{2}$ selectivity of the amorphous and crystalline $\mathrm{V}_{2} \mathrm{O}_{5}-\mathrm{WO}_{3} / \mathrm{TiO}_{2}$ catalysts reached $73 \%$ and $81 \%$ from $500{ }^{\circ} \mathrm{C}$, respectively. Figure 4c shows that $\mathrm{SO}_{2}$ affected the $\mathrm{NO}_{\mathrm{X}}$ removal efficiency of the $\mathrm{V}_{2} \mathrm{O}_{5}-\mathrm{WO}_{3} / \mathrm{TiO}_{2}$ catalysts at $250{ }^{\circ} \mathrm{C}$, which usually shows high deactivation caused by $\mathrm{SO}_{2}$. When $\mathrm{SO}_{2}$ gas was not added to the reactor, the $\mathrm{NO}_{X}$ removal efficiencies of the amorphous and crystalline $\mathrm{V}_{2} \mathrm{O}_{5}-\mathrm{WO}_{3} / \mathrm{TiO}_{2}$ were maintained at $80 \%$ and $99 \%$, and then rapidly decreased to $69 \%$ and $89 \%$ with the introduction of $\mathrm{SO}_{2}$, respectively. However, it returned to $80 \%$ and $99 \%$ when the $\mathrm{SO}_{2}$ was removed. When $\mathrm{SO}_{2}$ was introduced to the reactor, $\mathrm{SO}_{2}$ gas directly reacts with $\mathrm{V}_{2} \mathrm{O}_{5}-\mathrm{WO}_{3} / \mathrm{TiO}_{2}$ catalysts, and it produces the ammonium sulfates [15]. Ammonium sulfates slowly block the active sites of $\mathrm{V}_{2} \mathrm{O}_{5}-\mathrm{WO}_{3} / \mathrm{TiO}_{2}$ catalysts, and it leads to the decrease of NOx removal efficiency. When $\mathrm{SO}_{2}$ is removed, the produced ammonium sulfates were gradually removed, and the $\mathrm{V}_{2} \mathrm{O}_{5}-\mathrm{WO}_{3} / \mathrm{TiO}_{2}$ catalysts can be regenerated and return to the initial condition. The crystalline $\mathrm{V}_{2} \mathrm{O}_{5}-\mathrm{WO}_{3} / \mathrm{TiO}_{2}$ showed slightly high resistance against $\mathrm{SO}_{2}$ compared with amorphous $\mathrm{V}_{2} \mathrm{O}_{5}-\mathrm{WO}_{3} / \mathrm{TiO}_{2}$. Additionally, Figure $\mathrm{S} 2$ indicates that the crystalline $\mathrm{V}_{2} \mathrm{O}_{5}-\mathrm{WO}_{3} / \mathrm{TiO}_{2}$ catalyst showed higher $\mathrm{NO}$ removal efficiency than the amorphous $\mathrm{V}_{2} \mathrm{O}_{5}-\mathrm{WO}_{3} / \mathrm{TiO}_{2}$ catalyst in the temperature range of $150-500{ }^{\circ} \mathrm{C}$ under gas conditions containing $\mathrm{SO}_{2}$.

We conducted XPS, $\mathrm{NH}_{3}-\mathrm{TPD}$, and $\mathrm{H}_{2}$-TPR analyses to further elucidate the effect of crystallinity on the $\mathrm{NO}_{\mathrm{X}}$ removal performance of the $\mathrm{V}_{2} \mathrm{O}_{5}-\mathrm{WO}_{3} / \mathrm{TiO}_{2}$ catalysts, as shown in Figure 5. Figure 5a shows the survey peaks of the XPS results. The $\mathrm{O}$ 1s peaks can be fitted to two different peaks, i.e., chemisorbed oxygen $\left(\mathrm{O}_{\alpha}\right)$ at $530.9 \mathrm{eV}$ and lattice oxygen $\left(\mathrm{O}_{\beta}\right)$ at $530.1 \mathrm{eV}$ [24]. Surface chemisorbed oxygen plays a critical role in the oxidation of $\mathrm{NH}_{4}{ }^{+}$in $\mathrm{SCR}$ reactions as it is more mobile than lattice oxygen and promotes the oxidation of $\mathrm{NO}$ to $\mathrm{NO}_{2}[33,34]$. Therefore, the presence of $\mathrm{NO}_{2}$ induces a "fast SCR" and the $\mathrm{O}_{\alpha} /\left(\mathrm{O}_{\alpha}+\mathrm{O}_{\beta}\right)$ concentration ratio is the important value for the SCR reaction [33]. Figure $5 b$ clearly indicates that the $\mathrm{O}_{\alpha}$ ratio of the crystalline $\mathrm{V}_{2} \mathrm{O}_{5}-\mathrm{WO}_{3} / \mathrm{TiO}_{2}$ exceeded that of the amorphous $\mathrm{V}_{2} \mathrm{O}_{5}-\mathrm{WO}_{3} / \mathrm{TiO}_{2}$. V $2 \mathrm{p}$ was mainly composed of $\mathrm{V}^{5+}$ and $\mathrm{V}^{4+}$, and the two fitted peaks at 517.1 and $516.1 \mathrm{eV}$ could be attributed to $\mathrm{V}^{5+} 2 \mathrm{p}_{3 / 2}$ and $\mathrm{V}^{4+} 2 \mathrm{p}_{3 / 2}$, respectively [35]. According to previous studies, $\mathrm{V}^{4+}$ can promote the adsorption of oxygen and form reactive oxygen species on the surface of a catalyst, leading to fast redox cycles and improving the redox properties [36]. Figure $5 \mathrm{c}$ shows that crystalline $\mathrm{V}_{2} \mathrm{O}_{5}-\mathrm{WO}_{3} / \mathrm{TiO}_{2}$ contains a higher proportion of $\mathrm{V}^{4+}$ than amorphous $\mathrm{V}_{2} \mathrm{O}_{5}-\mathrm{WO}_{3} / \mathrm{TiO}_{2}$. The $\mathrm{V}^{4+} /\left(\mathrm{V}^{4+}+\mathrm{V}^{5+}\right)$ ratios of the crystalline and amorphous $\mathrm{V}_{2} \mathrm{O}_{5}-\mathrm{WO}_{3} / \mathrm{TiO}_{2}$ were 0.38 and 0.23 , respectively (Table 3). Additionally, the $\mathrm{W} 4 \mathrm{f}$ on the surface of the catalyst was mainly composed of $\mathrm{W}$ $4 \mathrm{f}_{7}$ and $\mathrm{W} 4 \mathrm{f}_{5}$, while the Ti $3 \mathrm{p}$ was centered at $35.76,38.12$, and $37.50 \mathrm{eV}$, with a hexavalent state in the form of $\mathrm{WO}_{3}[37,38]$. The $\mathrm{W} 4 \mathrm{f} \mathrm{XPS}$ results of $\mathrm{V}_{2} \mathrm{O}_{5}-\mathrm{WO}_{3} / \mathrm{TiO}_{2}$ did not differ significantly, as shown in Figure $5 \mathrm{~d}$. 
(a)

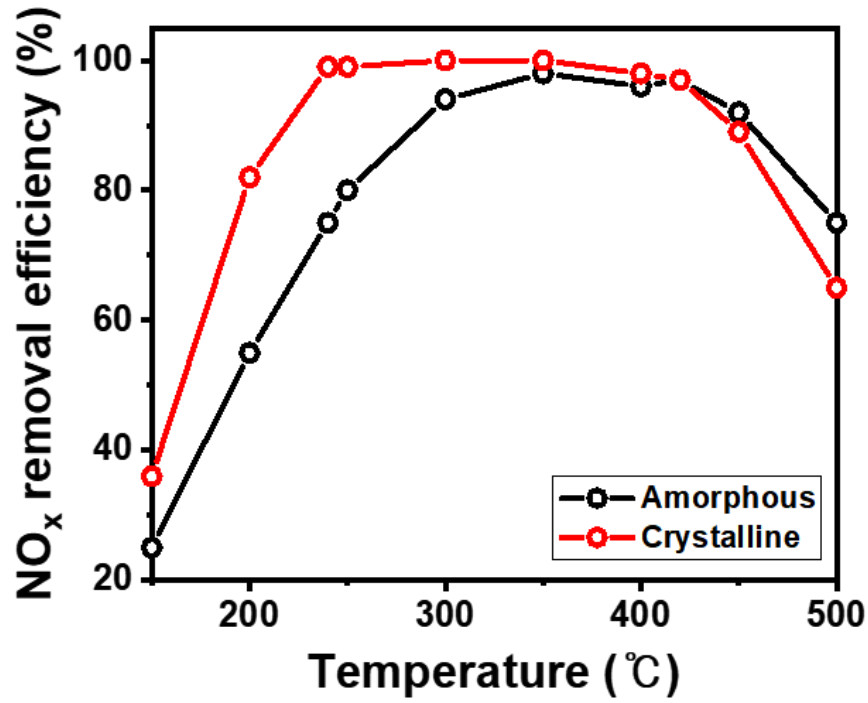

(b)

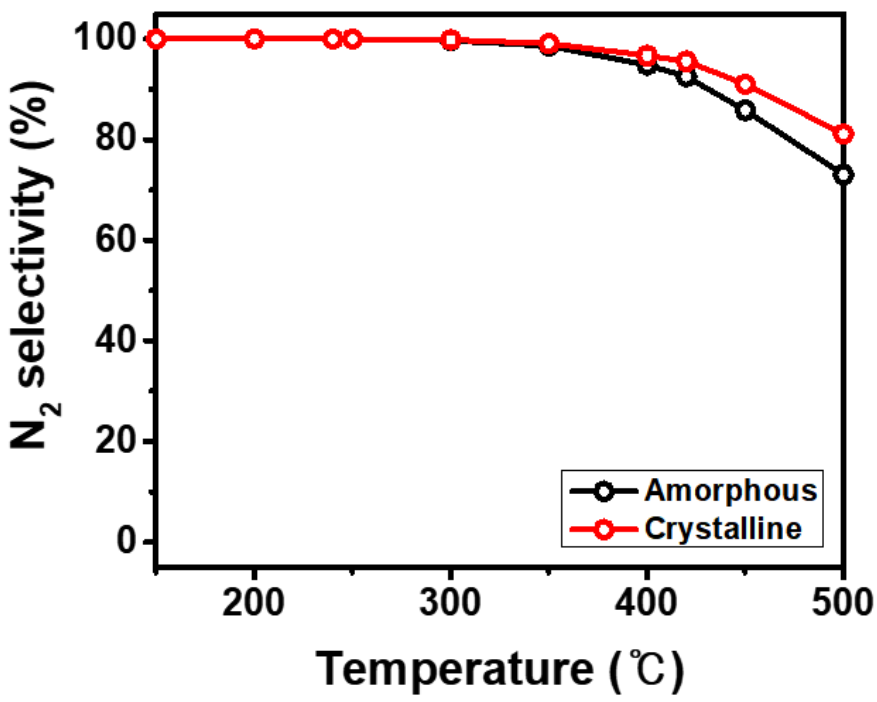

(c)

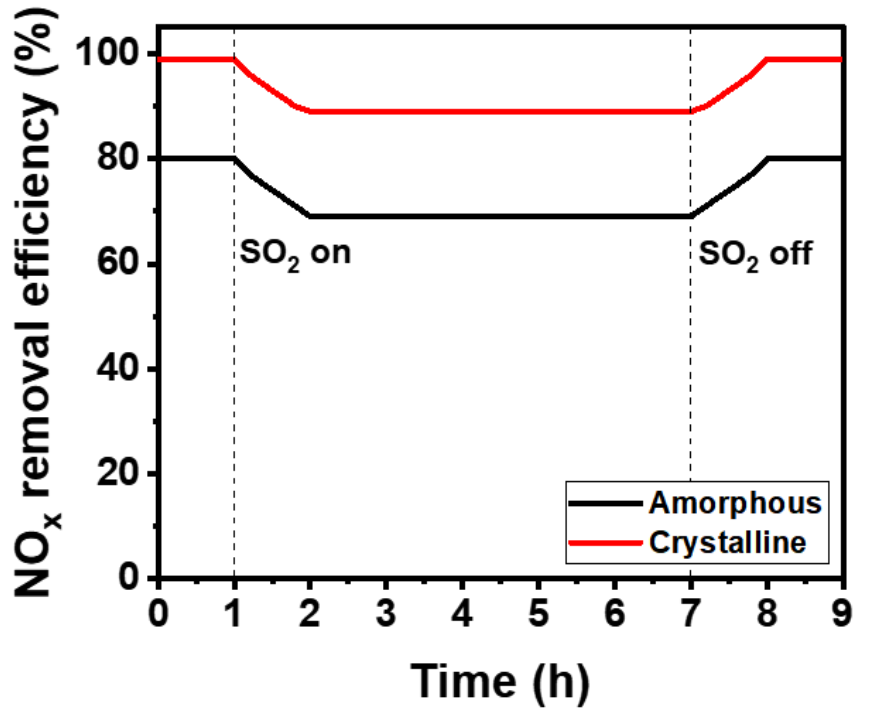

Figure 4. (a) NOx removal efficiency; (b) $\mathrm{N}_{2}$ selectivity of the $\mathrm{V}_{2} \mathrm{O}_{5}-\mathrm{WO}_{3} / \mathrm{TiO}_{2}$ catalysts and (c) $\mathrm{SO}_{2}$ tolerance of the $\mathrm{V}_{2} \mathrm{O}_{5}-\mathrm{WO}_{3} / \mathrm{TiO}_{2}$ catalysts with different crystal structures at $250{ }^{\circ} \mathrm{C}$ (black and red lines represent the amorphous and crystalline $\mathrm{V}_{2} \mathrm{O}_{5}-\mathrm{WO}_{3} / \mathrm{TiO}_{2}$, respectively). Reaction conditions: $[\mathrm{NO}] \&\left[\mathrm{NH}_{3}\right]=300 \mathrm{ppm},\left[\mathrm{O}_{2}\right]=5 \mathrm{vol} . \%$, [GHSV] $=60,000 \mathrm{~h}^{-1}$. 


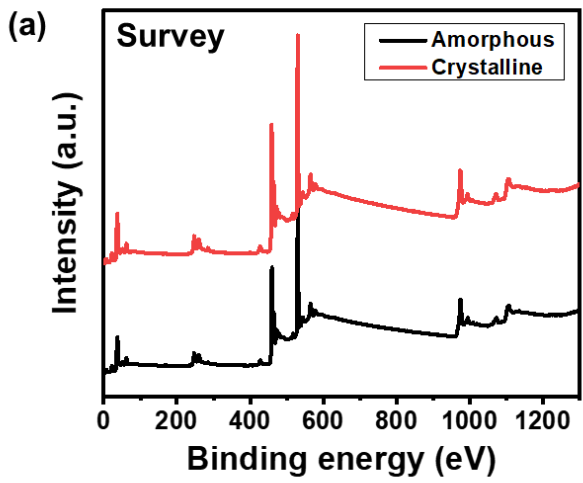

(c)

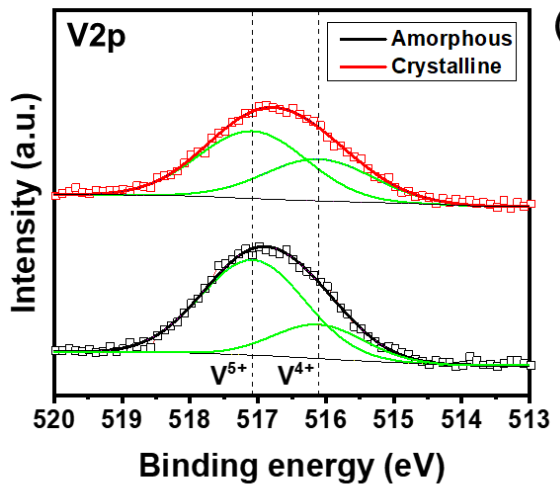

(e)

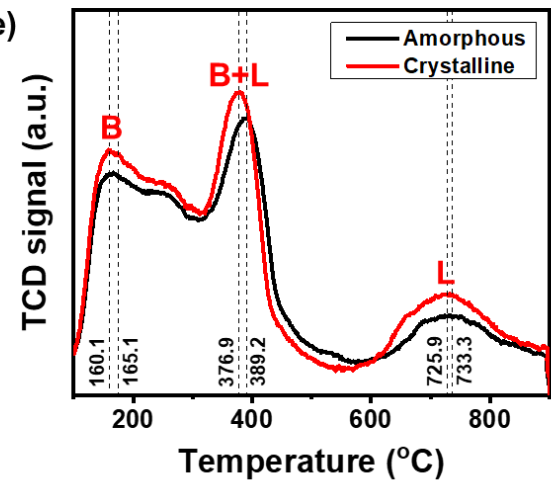

(b)

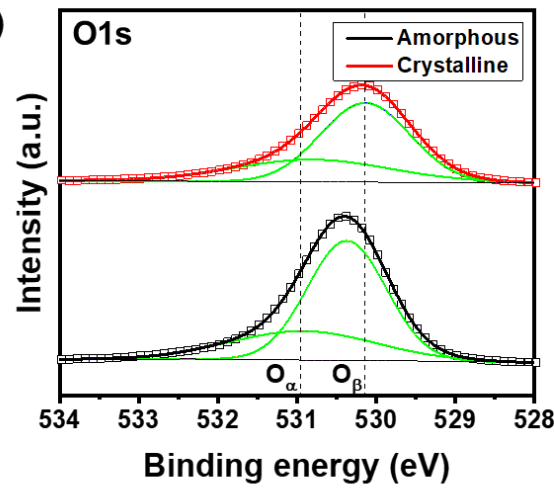

(d)

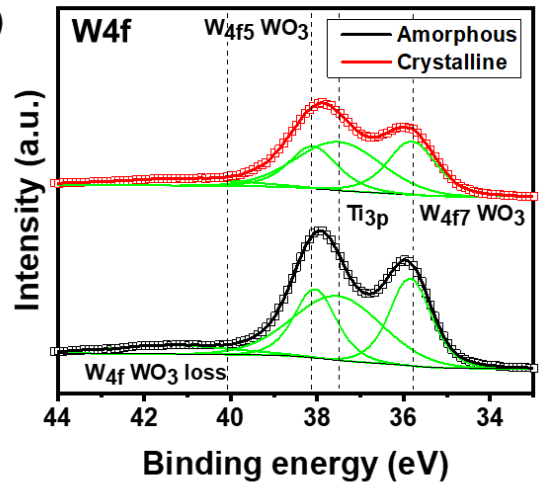

(f)

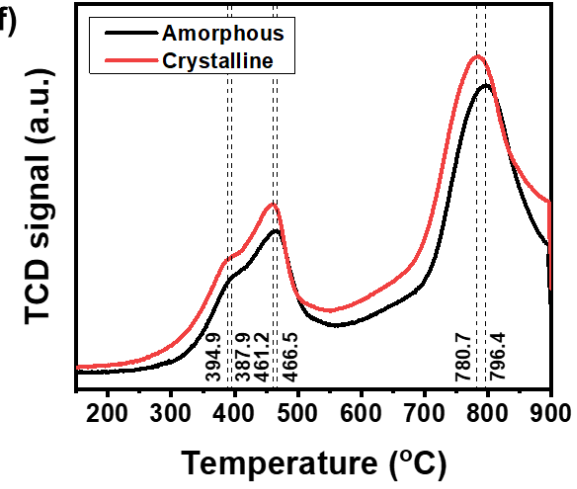

Figure 5. XPS spectra for (a) survey, (b) O1s, (c) V2p, and (d) W4f of amorphous $\mathrm{V}_{2} \mathrm{O}_{5}-\mathrm{WO}_{3} / \mathrm{TiO}_{2}$ and crystalline $\mathrm{V}_{2} \mathrm{O}_{5}-\mathrm{WO}_{3} / \mathrm{TiO}_{2}$ (e) $\mathrm{NH}_{3}-\mathrm{TPD}$ profiles of amorphous $\mathrm{V}_{2} \mathrm{O}_{5}-\mathrm{WO}_{3} / \mathrm{TiO}_{2}$ and crystalline $\mathrm{V}_{2} \mathrm{O}_{5}-\mathrm{WO}_{3} / \mathrm{TiO}_{2}$. B and $\mathrm{L}$ indicate Brønsted and Lewis acid sites, respectively. (f) $\mathrm{H}_{2}-\mathrm{TPR}$ profiles of amorphous $\mathrm{V}_{2} \mathrm{O}_{5}-\mathrm{WO}_{3} / \mathrm{TiO}_{2}$ and crystalline $\mathrm{V}_{2} \mathrm{O}_{5}-\mathrm{WO}_{3} / \mathrm{TiO}_{2}$.

Table 3. The ratio of $\mathrm{O} \alpha, \mathrm{V}^{4+}$ of amorphous and crystalline $\mathrm{V}_{2} \mathrm{O}_{5}-\mathrm{WO}_{3} / \mathrm{TiO}_{2}$ measured by $\mathrm{XPS}, \mathrm{NH}_{3}$-temperatureprogrammed desorption and $\mathrm{H}_{2}$-temperature-programmed reduction integral intensity of amorphous and crystalline $\mathrm{V}_{2} \mathrm{O}_{5}-\mathrm{WO}_{3} / \mathrm{TiO}_{2}$.

\begin{tabular}{ccccc}
\hline Sample & $\mathbf{O}_{\alpha} /\left(\mathbf{O}_{\alpha}+\mathbf{O}_{\beta}\right)$ & $\mathbf{V}^{4+} /\left(\mathbf{V}^{4+}+\mathbf{V}^{5+}\right)$ & $\mathbf{N H}_{3}$ Desorption $\left(\mathrm{cm}^{3} / \mathbf{g}\right)$ & $\mathbf{H}_{2}$ Consumption $\left(\mathrm{cm}^{\mathbf{3}} / \mathbf{g}\right)$ \\
\hline Amorphous & 0.30 & 0.23 & 13.74 & 40.17 \\
Crystalline & 0.33 & 0.38 & 16.97 & 46.06 \\
\hline
\end{tabular}

Figure 5e shows the $\mathrm{NH}_{3}$-TPD results for the amorphous and crystalline $\mathrm{V}_{2} \mathrm{O}_{5}$ $\mathrm{WO}_{3} / \mathrm{TiO}_{2}$ catalysts, such as the effects of their structures on the contents and strengths of the surface acidic sites of the catalysts $[39,40]$. The $\mathrm{NH}_{3}$-TPD profile of the amorphous and crystalline $\mathrm{V}_{2} \mathrm{O}_{5}-\mathrm{WO}_{3} / \mathrm{TiO}_{2}$ significantly varied in the temperature range of $100-900{ }^{\circ} \mathrm{C}$, in which $\mathrm{NH}_{3}$ desorption of $13.74 \mathrm{~cm}^{3} / \mathrm{g}$ and $16.97 \mathrm{~cm}^{3} / \mathrm{g}$ was measured, respectively (Table 3). The thermal conductivity detector (TCD) signals at the lower and higher temper- 
atures were considered to be Brønsted and Lewis acid sites [35,41], and the concentration of desorbed $\mathrm{NH}_{3}$ of the crystalline $\mathrm{V}_{2} \mathrm{O}_{5}-\mathrm{WO}_{3} / \mathrm{TiO}_{2}$ catalyst was higher, indicating a higher capability for adsorption. According to these results, the crystalline active materials contained more Brønsted and Lewis acid sites. We also produced $\mathrm{H}_{2}$-TPR profiles to investigate the redox properties of the amorphous and crystalline $\mathrm{V}_{2} \mathrm{O}_{5}-\mathrm{WO}_{3} / \mathrm{TiO}_{2}$. (Figure 5f) The amorphous $\mathrm{V}_{2} \mathrm{O}_{5}-\mathrm{WO}_{3} / \mathrm{TiO}_{2}$ exhibited have three apparent reduction peaks centered at $387.9^{\circ} \mathrm{C}, 466.5^{\circ} \mathrm{C}$, and $796.4^{\circ} \mathrm{C}$, which could be assigned to the co-reduction of $\mathrm{V}^{5+}$ to $\mathrm{V}^{3+}$, which corresponds to the surface vanadium species, reduction of $\mathrm{W}^{6+}$ to $\mathrm{W}^{4+}$, and reduction of $\mathrm{W}^{4+}$ to $\mathrm{W}^{0}$ in tungsten oxide [30,42]. However, the main reduction peaks of crystalline $\mathrm{V}_{2} \mathrm{O}_{5}-\mathrm{WO}_{3} / \mathrm{TiO}_{2}$ shifted to lower temperatures at $394.9^{\circ} \mathrm{C}, 461.2{ }^{\circ} \mathrm{C}$, and $780.7^{\circ} \mathrm{C}$, respectively, which could be because the higher crystallinity of the active materials reduced the large amount of $\mathrm{NO}_{\mathrm{X}}$, which promoted the release of lattice oxygen to further reduce the vanadium and tungsten species [42]. Consequently, we can confirm that the crystalline $\mathrm{V}_{2} \mathrm{O}_{5}-\mathrm{WO}_{3} / \mathrm{TiO}_{2}$ catalysts exhibited enhanced performance when $\mathrm{NH}_{3}$ gas adsorption and the reduction of $\mathrm{NO}$ and $\mathrm{NO}_{2}$ gas increased.

\section{Conclusions}

In this study, amorphous and crystalline $\mathrm{V}_{2} \mathrm{O}_{5}-\mathrm{WO}_{3} / \mathrm{TiO}_{2}$ catalysts were synthesized following two different heating methods to investigate the effects of crystallinity on the acidity, surface species, and performance of the catalysts. The isotropic heating method formed crystalline $\mathrm{V}_{2} \mathrm{O}_{5}$ and $\mathrm{WO}_{3}$ structures that contained more Brønsted and Lewis acid sites. The crystalline $\mathrm{V}_{2} \mathrm{O}_{5}-\mathrm{WO}_{3} / \mathrm{TiO}_{2}$ catalyst also had higher chemisorbed oxygen and $\mathrm{V}^{4+}$ species ratios than the amorphous catalyst. The crystalline structure of the $\mathrm{V}$ and $\mathrm{W}$ species significantly enhanced the SCR reactions on the surface of the catalysts, resulting in high $\mathrm{NO}_{X}$ removal efficiency and $\mathrm{N}_{2}$ selectivity over a wide temperature range of $200-450{ }^{\circ} \mathrm{C}$. These results may contribute to future studies on SCR catalysts and other catalyst systems.

Supplementary Materials: The following are available online at https:/ /www.mdpi.com/article/ 10.3390/nano11061452/s1, Figure S1: $\mathrm{NH}_{3}$ conversion of amorphous and crystalline $\mathrm{V}_{2} \mathrm{O}_{5}-\mathrm{WO}_{3} / \mathrm{TiO}_{2}$ catalyst, Figure S2: $\mathrm{NO}_{X}$ removal efficiency of Amorphous and Crystalline $\mathrm{V}_{2} \mathrm{O}_{5}-\mathrm{WO}_{3} / \mathrm{TiO}_{2}$ catalyst. Reaction conditions: $[\mathrm{NO}] \&\left[\mathrm{NH}_{3}\right]=300 \mathrm{ppm},\left[\mathrm{SO}_{2}\right]=0$ or $300 \mathrm{ppm},\left[\mathrm{O}_{2}\right]=5$ vol. $\%$, [GHSV] $=60,000 \mathrm{~h}^{-1}$.

Author Contributions: Conceptualization, J.W.L. and D.H.L.; methodology, M.-j.L.; validation, B.Y. and T.K.; writing —original draft preparation, M.S.L. and S.-I.K.; writing—review and editing, J.W.L. and D.H.L.; project administration, H.-D.K. All authors have read and agreed to the published version of the manuscript.

Funding: This research was funded by the Korea Institute of Industrial Technology (KITECH), grant number JA200009; the Ministry of Trade, Industry and Energy, South Korea (MOTIE), grant number 20005721; and the National Research Foundation of Korea, grant numbers NRF-2020R1C1C1013900 and NRF-2017M3A7B4049466.

Data Availability Statement: Data are contained within the article.

Conflicts of Interest: The authors declare no conflict of interest.

\section{References}

1. Boningari, T.; Smirniotis, P.G. Impact of nitrogen oxides on the environment and human health: Mn-based materials for the NOX abatement. Curr. Opin. Chem. Eng. 2016, 13, 133-141. [CrossRef]

2. Li, K.; Thompson, S.; Peng, J. Modelling and prediction of NOx emission in a coal-fired power generation plant. Control. Eng. Pract. 2004, 12, 707-723. [CrossRef]

3. Lee, M.-J.; Kim, D.-H.; Lee, M.; Ye, B.; Jeong, B.; Lee, D.; Kim, H.-D.; Lee, H. Enhanced NOx removal efficiency for SCR catalyst of well-dispersed Mn-Ce nanoparticles on hexagonal boron nitride. Environ. Sci. Pollut. Res. 2019, 26, 36107-36116. [CrossRef] [PubMed]

4. Forzatti, P.; Nova, I.; Tronconi, E. Enhanced NH3 Selective Catalytic Reduction for NOx Abatement. Angew. Chem. 2009, 121, 8516-8518. [CrossRef] 
5. Ye, B.; Lee, M.; Jeong, B.; Kim, J.; Lee, D.; Baik, J.; Kim, H. Partially reduced graphene oxide as a support of Mn-Ce/TiO2 cat-alyst for selective catalytic reduction of NOx with NH3. Catal. Today 2019, 328, 300-306. [CrossRef]

6. Hoek, G.; Krishnan, R.M.; Beelen, R.; Preters, A.; Ostro, B.; Brunekreef, B. Long-term air pollution exposure and cardiores-piratory mortality: A review. Environ. Health 2013, 12, 43. [CrossRef] [PubMed]

7. Radojevic, M. Reduction of nitrogen oxides in flue gases. Environ. Pollut. 1998, 102, 685-689. [CrossRef]

8. Jeong, B.; Ye, B.; Kim, E.-S.; Kim, H.-D. Characteristics of selective catalytic reduction (SCR) catalyst adding graphene-tungsten nanocomposite. Catal. Commun. 2017, 93, 15-19. [CrossRef]

9. Roy, S.; Hegde, M.; Madras, G. Catalysis for NOx abatement. Appl. Energy 2009, 86, 2283-2297. [CrossRef]

10. Busca, G.; Lietti, L.; Ramis, G.; Berti, F. Chemical and mechanistic aspects of the selective catalytic reduction of $\mathrm{NO}(\mathrm{X})$ by ammonia over oxide catalysts: A review. Appl. Catal. B Environ. 1998, 18, 1-36. [CrossRef]

11. Yao, X.; Kong, T.; Yu, S.; Li, L.; Yang, F.; Dong, L. Influence of different supports on the physicochemical properties and de-nitration performance of the supported Mn-based catalysts for NH3-SCR at low temperature. Appl. Surf. Sci. 2017, 402, 208-217. [CrossRef]

12. Liu, F.; Shan, W.; Lian, Z.; Xie, L.; Yang, W.; He, H. Novel MnWOx catalyst with remarkable performance for low tempera-ture NH3-SCR of NOx. Catal. Sci. Technol. 2013, 3, 2699-2707. [CrossRef]

13. Huang, B.; Huang, R.; Jin, D.; Ye, D. Low temperature SCR of NO with NH3 over carbon nanotubes supported vanadium oxides. Catal. Today 2007, 126, 279-283. [CrossRef]

14. Huang, Z.; Zhu, Z.; Liu, Z.; Liu, Q. Formation and reaction of ammonium sulfate salts on V2O5/AC catalysts during selective catalytic reduction of nitric oxide by ammonia at low temperatures. J. Catal. 2003, 214, 213-219. [CrossRef]

15. Muzio, L.; Bogseth, S.; Himes, R.; Chien, Y.; Dunn-Rankin, D. Ammonium bisulfate formation and reduced load SCR opera-tion. Fuel 2017, 206, 180-189. [CrossRef]

16. Xu, L.; Yang, Q.; Hu, L.; Wang, D.; Peng, Y.; Shao, Z.; Lu, C.; Li, J. Insights over titanium modified FeMgOx catalysts for se-lective catalytic reduction of NOx with NH3: Influence of precursors and crystalline structures. Catalysts 2019, 9, 560. [CrossRef]

17. Yu, L.; Zhong, Q.; Deng, Z.; Zhang, S. Enhanced NOx removal performance of amorphous Ce-Ti catalyst by hydrogen pretreatment. J. Mol. Catal. A Chem. 2016, 423, 371-378. [CrossRef]

18. Wang, C.; Yang, S.; Chang, H.; Peng, Y.; Li, J. Dispersion of tungsten oxide on SCR performance of V2O5AWO3/TiO2: Acidity, surface species and catalytic activity. Chem. Eng. J. 2013, 225, 520-527. [CrossRef]

19. Inomata, Y.; Hata, S.; Mino, M.; Kiyonaga, E.; Morita, K.; Hikino, K.; Yoshida, K.; Kubota, H.; Toyao, T.; Shimizu, K.; et al. Bulk vanadium oxide versus conventional V2O5/TiO2: NH3-SCR catalysts working at a low tem-perature below $150{ }^{\circ} \mathrm{C}$. ACS Catal. 2019, 9, 9327-9331. [CrossRef]

20. Inomata, Y.; Hata, S.; Kiyonaga, E.; Morita, K.; Yoshida, K.; Haruta, M.; Murayama, T. Synthesis of bulk vanadium oxide with a large surface area using organic acids and its low-temperature NH3-SCR activity. Catal. Today 2020. [CrossRef]

21. Lian, Z.; Deng, H.; Xin, S.; Shan, W.; Wang, Q.; Xu, J.; He, H. Significant promotion effect of the rutile phase on V2O5/TiO2 catalysts for NH3-SCR. Chem. Commun. 2021, 57, 355-358. [CrossRef]

22. Lian, Z.; Li, Y.; Shan, W.; He, H. Recent Progress on Improving Low-Temperature Activity of Vanadia-Based Catalysts for the Selective Catalytic Reduction of $\mathrm{NO}_{x}$ with Ammonia. Catalysts 2020, 10, 1421. [CrossRef]

23. Chen, H.; Xia, Y.; Fang, R.; Huang, H.; Gan, Y.; Liang, C.; Zhang, J.; Zhang, W.; Liu, X. The effects of tungsten and hydro-thermal aging in promoting NH3-SCR activity on V2O5/WO3-TiO2 catalysts. Appl. Surf. Sci. 2018, 459, 639-646. [CrossRef]

24. Li, S.; Huang, W.; Xu, H.; Chen, T.; Ke, Y.; Qu, Z.; Yan, N. Alkali-induced deactivation mechanism of V2O5-WO3/TiO2 cata-lyst during selective catalytic reduction of $\mathrm{NO}$ by $\mathrm{NH} 3$ in aluminum hydrate calcining flue gas. Appl. Catal. B Environ. 2020, 270, 118872. [CrossRef]

25. Choi, H.C.; Jung, Y.M.; Bin Kim, S. Size effects in the Raman spectra of TiO2 nanoparticles. Vib. Spectrosc. 2005, 37, 33-38. [CrossRef]

26. Arfaoui, J.; Boudali, L.K.; Ghorbel, A.; Delahay, G. Effect of vanadium on the behaviour of unsulfated and sulfated Ti-pillared clay catalysts in the SCR of NO by NH3. Catal. Today 2009, 142, 234-238. [CrossRef]

27. Lai, J.-K.; Wachs, I.E. A Perspective on the Selective Catalytic Reduction (SCR) of NO with NH3 by Supported V2O5-WO3/TiO2 Catalysts. ACS Catal. 2018, 8, 6537-6551. [CrossRef]

28. Park, K.H.; Cha, W.S. Effect of vanadium oxide loading on SCR activity and SO2 resistance over TiO2-supported V2O5 commercial De-NOX catalysts. Appl. Chem. Eng. 2012, 23, 485-489.

29. Reddy, B.M.; Khan, A.; Yamada, Y.; Kobayashi, T.; Loridant, S.; Volta, J.-C. Surface Characterization of CeO2/SiO2 and V2O5/CeO2/SiO2 Catalysts by Raman, XPS, and Other Techniques. J. Phys. Chem. B 2002, 106, 10964-10972. [CrossRef]

30. Zhang, Y.; Guo, W.; Wang, L.; Song, M.; Yang, L.; Shen, K.; Xu, H.; Zhou, C. Characterization and activity of V2O5-CeO2/TiO2$\mathrm{ZrO} 2$ catalysts for NH3-selective catalytic reduction of NOx. Chin. J. Catal. 2015, 36, 1701-1710. [CrossRef]

31. Han, H.; Choi, H.; Mhin, S.; Hong, Y.R.; Kim, K.M.; Kwon, J.; Ali, G.; Chung, K.Y.; Je, M.; Umh, H.M.; et al. Advantageous crystalline-amorphous phase boundary for enhanced electrochemical water oxi-dation. Energy Environ. Sci. 2019, 12, $2443-2454$. [CrossRef]

32. Falqui, A.; Loche, D.; Casu, A. In Situ TEM Crystallization of Amorphous Iron Particles. Crystals 2020, 10, 41. [CrossRef]

33. Zhang, S.; Zhang, L.; Shi, L.; Fang, C.; Li, H.; Gao, R.; Huang, L.; Zhang, J. In situ supported MnOx-CeOx on carbon nano-tubes for the low-temperature selective catalytic reduction of NO with NH3. Nanoscale 2013, 5, 1127-1136. [CrossRef] 
34. Liu, F.; He, H. Structure-activity relationship of iron titanate catalysts in the selective catalytic reduction of NOX with NH3. J. Phys. Chem. C 2010, 114, 16929-16936. [CrossRef]

35. Jiang, Y.; Gao, X.; Zhang, Y.; Wu, W.; Song, H.; Luo, Z.; Cen, K. Effects of PbCl2 on selective catalytic reduction of NO with NH3 over vanadia-based catalysts. J. Hazard. Mater. 2014, 274, 270-278. [CrossRef]

36. Chen, Z.; Wu, X.; Ni, K.; Shen, H.; Huang, Z.; Zhou, Z.; Jing, G. Molybdenum-decorated V2O5-WO3/TiO2: Surface engineering toward boosting the acid cycle and redox cycle of NH3-SCR. Catal. Sci. Technol. 2021, 11, 1746-1757. [CrossRef]

37. Zhang, S.; Li, H.; Zhong, Q. Promotional effect of F-doped V2O5-WO3/TiO2 catalyst for NH3-SCR of NO at low-temperature. Appl. Catal. A Gen. 2012, 435-436, 156-162. [CrossRef]

38. Zhan, S.; Zhang, H.; Zhang, Y.; Shi, Q.; Li, Y.; Li, X.J. Efficient NH3-SCR removal of NOX with highly ordered mesoporous WO3 (X)-CeO2 at low temperatures. Appl. Catal. B Environ. 2017, 203, 199-209. [CrossRef] [PubMed]

39. Greenhalgh, B.; Fee, M.; Dobri, A.; Moir, J.; Burich, R.; Charland, J.-P.; Stanciulescu, M. DeNOx activity-TPD correlations of NH3-SCR catalysts. J. Mol. Catal. A Chem. 2010, 333, 121-127. [CrossRef]

40. Xie, G.; Liu, Z.; Zhu, Z.; Liu, Q.; Ge, J.; Huang, Z. Simultaneous removal of SO2 and NOx from flue gas using a CuO/Al2O3 catalyst sorbentII. Promotion of SCR activity by SO2 at high temperatures. J. Catal. 2004, 224, 42-49. [CrossRef]

41. Luo, J.; Wang, D.; Kumar, A.; Li, J.; Kamasamudram, K.; Currier, N.; Yezerets, A. Identification of two types of Cu sites in $\mathrm{Cu} /$ SSZ-13 and their unique responses to hydrothermal aging and sulfur poisoning. Catal. Today 2016, 267, 3-9. [CrossRef]

42. Wu, X.; Yu, W.; Si, Z.; Weng, D. Chemical deactivation of V2O5-WO3/TiO2 SCR catalyst by combined effect of potassium and chloride. Front. Environ. Sci. Eng. 2013, 7, 420-427. [CrossRef] 